Article

\title{
An Indigenous Research Methodology That Employs Anishinaabek Elders, Language Speakers and Women's Knowledge for Sustainable Water Governance
}

\author{
Susan Chiblow ${ }^{+}(\mathbb{B}$ \\ Faculty of Environmental Studies and Urban Change, York University, Toronto, ON M3J 1P3, Canada; \\ suebellchiblow@gmail.com; Tel.: +1-(705)-975-1604 \\ † Also known as Ogamauh Annag Qwe in Anishinaabemowin.
}

Received: 31 July 2020; Accepted: 28 October 2020; Published: 31 October 2020

check for updates

\begin{abstract}
Indigenous research paradigms are congruent to Indigenous worldviews and have become more dominant in areas such as Indigenous policy and education. As Indigenous research paradigms continue to gain momentum, the historical legacy of unethical research is addressed as more Indigenous communities and organizations develop their own research protocols. There is a plethora of articles explaining Indigenous research methodologies, but few examine the inclusion of the knowledge from Elders, language speakers, and Indigenous women in sustainable water governance. My Indigenous research methodology draws on the works of Indigenous scholars Shawn Wilson, Linda Smith, and Margaret Kovach, with specific focus on Wendy Geniusz's Biskaabiiyang. My Indigenous research methodology is specific to the Anishinaabe territory of the Great Lakes region and includes Anishinaabek Elders, Anishinaabemowin (Ojibway language) speakers, and Anishinaabek women. This article seeks to contribute to Indigenous research paradigms and methods by elucidating the importance of engaging Anishinaabek Elders, Anishinaabemowin speakers, and Anishinaabek women in sustainable water governance.
\end{abstract}

Keywords: worldview; responsibility; respect; colonialization; relationality

I am in the infancy stages of learning Anishinaabemowin that I use in this paper. I am only a beginner learner in all things that I do. It is my understanding that there are many dialects of Anishinaabemowin and, since there are multiple people I am learning from, the dialect used may vary throughout this paper. I have created an Anishinabemowin glossary at the end of the document. I work mostly with fluent language speakers from the Robinson Huron Treaty territory, specifically Mishi-zaageeng (north part of Lake Huron). I humbly request your patience with my infancy in the use of Anishinaabemowin.

\section{Introduction}

This journey started from a conversation with an Anishinaabe Dennis Councillor about what is research. We were having a conversation about Anishinaabemowin (Anishinabek language). We discussed how the English language changes meanings, concepts, our worldview, and therefore losing our teachings. Meighan (2020) explained that language shapes our beliefs, our values and informs our worldview [1]. The conversation focused on g'giikendaaswinmin (our knowledge) about the lands, N'bi (the waters), the universe, and how we as Anishinabek peoples live our lives. We seek g'giikendaaswinmin as part of who we are. We always seek balance. This is who we are as Anishinaabek Peoples. Absolon (2011) reiterated that "Indigenous peoples have always had means of seeking and accessing knowledge" [2] (p. 23). Linda Toulouse, a fluent Anishinaabe language speaker, 
explained to me that ndod-ne-aah-non chi-kendaaswin (I am searching for knowledge) is what all Anishinabek did and still do. This is what I seek to do, by utilizing Indigenous research paradigms (IRP) and by listening to Anishinaabek Elders, language speakers, and women.

As an Anishinaabek woman from the Robinson Huron Treaty territory, I want to explore Anishinaabek women's N'bi water knowledge, how we can improve our relationship to N'bi, and understand Anishinaabek women's concepts of reconciliation and relationships to the moon. My research approach employs Anishinaabek Elders who are fluent language speakers, primarily women. I utilize the knowledge and the language they have shared to assist me in better understanding our relationships and responsibilities to $N^{\prime}$ bi. I have often heard Anishinaabek Elders speak of the importance of understanding the language to truly grasp Anishinaabek worldviews. McGregor (2004) explained the connectedness between language, culture, and worldviews [3]. On several occasions, language speakers share their knowledge in Anishinaabemowin. They explain the concepts and how these differ from the English language. It is therefore important to work with women, Elders and those who are fluent language speakers when conducting Indigenous research.

Research in Indigenous communities has not always benefited the community, nor has it been done ethically. As Mosby (2013) reported, nutritional studies conducted on children in residential schools had no parental notification or approval [4]. Hall et al. (2016) also described how many researchers utilize the "helicopter approach", where researchers come into the communities to collect data, leaving with no benefits to the community [5]. Debassige (2010) explained how other researchers, such as Kovach, Archibald and Wilson, described the historical legacy of research in Indigenous communities as being horrific and how respectful research is emerging as more Indigenous peoples become scholars [6]. As more Indigenous researchers enter western education institutions, research on Indigenous peoples and in Indigenous communities is assisting in defining new concepts. This process allows Indigenous Peoples and communities to gain control over how research is conducted. Kovach (2009) indicated that Indigenous methodologies are distinct [7]. Indigenous scholars and communities are now driving research, including how it is conducted. Lambert (2014) stated "it is my belief that Indigenous research must produce new knowledge and information that can benefit our communities, move our communities forward, and create stronger communities of decolonized residents filled with self-determination and self-worth" [8] (p. 14). Indigenous communities and organizations have developed protocols, committees, and ethical applications to address historical grievances with colonial research processes. These Indigenous-developed processes are changing the research process and ensuring the research is beneficial to communities. Wilson (2008) stated "A precursor for this change has been the growing number of Indigenous people who have excelled in academia and who focus their study on their own peoples" [9] (p. 15). He explained that this change has led to the introduction of "Indigenous beliefs, values and customs into the research process, and this in turn has helped research become much more culturally sensitive to Indigenous peoples" [9] (p. 15).

The intent of this paper is to provide my understanding of the importance in working with Elders and language speakers through the lens of Anishinabek ontology-epistemology when conducting research [10]. I will argue the importance including Anishinabek women in water governance and will convey the ndakenjigwen approach utilized in ndod-ne-aah-non chi-kendaaswin with a specific focus on Anishinaabek g'giikendaaswinmin (knowledge) from the Great Lakes Region.

The goal is to provide insight into the Indigenous research methodologies I have employed to conduct ndakenjigwen with Anishinabek women and their kendaaswin. Following the instructions provided by Anishinaabek Elders, I focus on Anishinaabek Peoples from the Great Lakes region, which is inclusive to my territory. I also focus on grassroots peoples, mishoomsinaanik (grandfathers), nookmisinaanik (grandmothers), traditional knowledge holders, and people who are often left out of the conversation on such matters. It is beyond the scope of this research to be inclusive of all Indigenous Peoples. 


\section{Rationale}

It is not a new fact to learn of and understand how historical research has damaged relationships between Indigenous Peoples and researchers. Several scholars, including Margaret Kovach (2009), Shawn Wilson (2008), and Ian Mosby (2013), have written about the manipulative and experimental types of research done on Indigenous Peoples and in their communities [4,7,9]. Lambert (2014) cited Martin, stating "As Western research methods have come under scrutiny by Indigenous scholars, there has been a reframing of research paradigms and programs by Indigenous academics, researchers, and thinkers" [8] (p. 15). The changing research paradigms have First Nation communities and organizations producing protocols, ethical frameworks, research agreements, and research applications to address the historical damage created by non-ethical research. Wilson (2008) cited Rigney and explained how Indigenous Peoples are now at a stage where they insist on research and research designs which contributes to their communities' needs [9]. Absolon (2011) highlighted how Indigenous Peoples acknowledge our past, present and future [2]. Indigenous Peoples have learnt from the past, focusing on today to protect future generations from bearing the burden of mistrust, and non-beneficial, unethical research.

In response to the non-ethical research conducted on First Nations Peoples, the Assembly of First Nations (AFN), the national advocacy organization representing the First Nations in Canada, produced an Ethics Research in First Nations document which described the challenges of conducting ethical research and the tools for enabling ethical research [11]. AFN also produced a discussion document, First Nations Ethics Guide on Research and Aboriginal Traditional Knowledge, which lists the principles of a draft framework when working with "Aboriginal Knowledge" [12]. This document lists a "National Inventory of ATK (Aboriginal Traditional Knowledge) Resources and Protocols from 2007-2008" [12]. The list includes several individual First Nation communities that have drafted their own research protocols, such as Akwesanse.

Many individual First Nation communities have developed their own research protocols to ensure the research benefits their people and communities. The Mohawk Council of Akwesanse accepted their "Protocol for Review of Environment and Scientific Research Proposals" [13]. This document has their "Akwesanse Good Research Model", which is based on their principles and has an application process for researchers wanting to conduct research in their community [13]. Many First Nations in the same geographic region will utilize an Indigenous organization to develop research frameworks and protocols.

Indigenous organizations have developed frameworks to support research projects that utilize their principles, such as the Ontario Federation of Indigenous Friendship Centers, who developed a "Utility Self-Voicing Access Inter-Relationality Research Framework" [14]. The First Nation communities on Manitoulin Island also established the Manitoulin Anishinaabek Research Review Committee (MARRC) with a required application process. The application needs to be approved by the Committee prior to any research being conducted on Manitoulin Island with the First Nation communities. This detailed application addresses community involvement; ownership, control, access, and possession; risks and benefits to the participants and community; Anishinabek knowledge, and being respectful of the Seven Grandfather Teachings of love, humility, respect, honesty, bravery, truth, and wisdom (these teachings have different names, such as The Seven Sacred Teachings, and may be slightly different). More information on the Seven Teachings can be found in MARRC's Guidelines for Ethical Aboriginal Research [15]. I am familiar with the MARRC as I had original intentions of accessing Anishinaabek women's knowledge from the First Nation communities on Manitoulin Island prior to COVID 19.

The historic unethical research conducted on Indigenous Peoples has provided opportunities for Indigenous organizations and First Nation communities to develop their own research protocols ensuring ethical research. These changes have utilized Indigenous research paradigms as the alternative way of conducting research. They employ Indigenous epistemology, ontology, and axiology. The Indigenous-driven research protocols bring communities into the research process and ensure the research is more visible and ethical to the communities $[2,5,7,8,11,15-18]$. These changes to how research 
is conducted in First Nation communities by Indigenous organizations and First Nation communities are addressing the historical legacy of colonization and unethical and non-beneficial research.

Colonization has had devasting effects on women, often silencing their voices, dismissing them, or not seeking their knowledge [8]. Women's voices and knowledge are often ignored in water policies, strategies, and governance $[19,20]$. Women's knowledge is suppressed and, if not honored, the imbalance of male and female energies could cause the destruction of Mother Earth [21]. The continuous ignoring of Anishinabek women is embedded in colonialism, is historic, and persists today. The historicol disregard for Anishinabek women's knowledge stems from the original settlers who "explored" the lands. These observations and experiences belonged to European men whose interactions and assumptions were based on their cultural views of gender, which reflected the role of women in European societies [22]. These non-Indigenous explorers displaced Anishinaabek women by trying to erase g'giikendaaswinmin systems and legal and political realities. Anderson et al. (2013) explained how limited attention has been paid to gendered impacts of current government water management policy [18]. Women's voices have been silenced by colonial mindsets and eliminated from self-governance, including N'bi governance. As Sayers and MacDonald (2001) state, “There is a voluminous amount of literature on self-government in general ... [U]nfortunately, almost all of this material is lacking in any sort of gender analysis ... and therefore did not and could not address issues specific to First Nations women" [22] (p. 9). Many Anishinabek women are re-establishing their relationships with, and responsibilities to N'bi through various means, such as the Water Walks, Idle No More, and N'bi ceremonies. There are now many Indigenous women scholars who are conducting ethical research with and on Indigenous women. These scholars promote women's voices and knowledge as key to self-determination including water governance.

In working with language speakers, I wanted to understand the Anishinaabek worldview on what research is. Did we do research and how did we do research? I therefore asked Emma Meawasige, who is a fluent Anishinaabe language speaker, how would we say "research" in Anishinaabemowin. She explained that there is no such word. However, the act of doing, the act of searching for something you need to know, would be "ndakenjigewin". Lambert (2014) stated, "The term 'research' is inextricably linked to European imperialism and colonialism that many Indigenous languages do not have a word that has similar concepts to the English word research" [8] (p. 13). This is the Anishinaabek approach to minobimadziwin (living the good life), which is different from western institutions' concepts of "research". Absolon and Willett (2005) explained that research has racist and colonial baggage, and we must find new words to liberate and decolonize our approaches for gathering knowledge [23]. I will therefore use ndakenjigwen in place of research in the proper context, unless it is being cited, because the " $n$ " at the beginning of Anishinaabemowin phrases/words indicates it is 'me' doing the action. In my infancy in understanding Ansihinaabemowin, the core word remains the same, with a new letter being added for 'us', 'you', and 'them'. It is my intent to better understand the language by utilizing Anishinaabe language speakers and those whose voices have often been silenced or ignored by colonization in sustainable water governance.

\section{N'dakenjigwen Approach, Methodology, and Positionality}

N'bi has always been a part of my personal interest as an Anishinaabe women living in the Great Lakes territory. My relationship to N'bi and the lands has significantly influenced my identity. N'bi has had a profound effect on my life. I understood as a young person how N'bi is "an important source of healing" and "during times of difficulty is the time to get healing from the water" $[10,24]$. I understood that water is regarded as "sacred" and is a "powerful medicine" with "life giving properties" [10,11,24-26]. I would sit on the riverbanks praying, listening to N'bi, feeling the power, and allowing it to take me to a place of tranquility. I have learned how N'bi has "curative powers" [10,24,25] and acts as medicine [16]. Many Elders simply state that water is a living entity or water is alive, with its own personalities, and water is life [10,11,24,25]. Understanding that N'bi has its own agency and can govern itself is sustainable water governance. 
Specifically, Ndakenjigwen into "N'bi G'giikendaaswinmin" (water knowledge) explores humanity's relationship to N'bi and how improving this relationship can support well-being for $\mathrm{N}$ 'bi, other beings, and humanity. There are three areas of study that address my overall goal. Ndakenjigwen will explore:

1. N'bi governance and Anishinaabek women: How does Anishinaabek law construct the role of women in decision making about $\mathrm{N}^{\prime} \mathrm{bi}$ ?

2. Reconciliation and relationships with N'bi: Can the broader discourse in Canada about reconciliation assist with improving humanity's relationship to $N^{\prime}$ bi? How can reconciliation assist with reconciling different legal orders and governance structures? How can the concept of reconciliation assist with addressing environmental conflicts?

3. Anishinaabek law and Nookomis Giizis: What are the relationships and responsibilities between Anishinaabek and Nookomis Giizis and how can these relationships and responsibilities inform sustainable N'bi governance including women's roles in N'bi governance decision making?

Ndakenjigwen does not intend to distill discrete pieces of knowledge, but rather how we can improve humanity's relationship to N'bi, inform reconciliation, explore Anishinabek law, and construct Anishinaabek women's knowledge.

The methodologies employed in this research are place-based, as g'giikendaaswinmin comes from the lands, the ceremonies, and the Elders in the territory that I live in. This drives my positionality. Ndakenjigwen approach is distinctly Anishinaabek, as I am Anishinaabek from the Great Lakes region, where my Anishinaabek ancestors have lived forever. I use the teachings from my ancestors through ceremony and the teachings from the lands of which I am part. Specifically, my work draws on Indigenous theoretical frameworks that emphasize responsibility and relationships to place [7,9]. My approach ties decolonizing methodologies, guided by groundbreaking work by Linda Smith on Indigenous methodologies. It includes Wendy Geniusz' (2009) Biskaabiiyang, in which researchers engage in self-examination, recognize colonization, engage in decolonization in order be ready to engage with knowledge, teachings and stories [27]. Biskaabiiyang emphasizes community-based participatory research and my work follows this model, using interviews with Elders, community members, key informants, focus groups, and participation in ceremonies [27]. Wilson et al. (2019) explained that community-based research focuses on topics of real importance to the community and seeks to advance positive change [28]. I follow guidelines for research developed by various First Nation organizations (RCAP, 1999; First Nations Centre, 2007; National Aboriginal Health Organization, 2010). I also maintain continuous communication with an Elder advisor utilized by McGregor and Plain in her water governance research [29]. These methodological and ethical commitments are best to ensure minimal risk to Anishinaabek participants. They also ensure cultural sensitivity and appropriateness in the documentation of knowledge. Ndakenjigwen methods attempt to align with the Anishinaabek epistemology-ontology in a way that promotes trust between the researcher and the participants. These research methodologies also enable the researcher to develop a deeper understanding of the specific knowledge being shared and how that knowledge can be carried and should be used. This is my personal journey: searching for g'giikendaaswinmin by continuously striving for minobimaadzwin (the good life) and, focusing on meaningful relationships between myself and the participants.

My community-based approach is based on territory. The community I work with are Anishinaabek Elders, language speakers, and women from the Great Lakes territory. The relevant community is not a geographic or political community but is comprised of participants who have expressed interest or concern for the state of the waters. The participants are the community who are influencing water security and governance with g'giikendaaswinmin. Many of the participants were already known to me, but in some instances, participants recommended others who have knowledge on the topics being explored. I contacted the already known participants, shared information about the research, and set a date and time for the interview. Due to COVID 19, my ethics were revised to include utilizing 
ZOOM or telephone conversations. I had already completed Elder interviews, which was a relief as conversations with Elders should always be face to face.

The wave of Indigenous scholars bringing their research methodologies into research is the approach I employ in conducting research. Cora Weber-Pillwax, as cited in Debassige (2010), explained that people involved in Indigenous research "must ensure that the three Rs-Respect, Reciprocity, and Relationality-are guiding the research" [6] (p. 15). I further the three Rs to include responsibility, relevance, and reflection $[6,15-19,30]$. These form the basis of my research with Indigenous Peoples.

\section{Elder Inclusiveness}

In many Indigenous communities, Elders are considered the backbone of the communities, for they are the wisdom keepers, the keepers of the language, possess cultural knowledge, and simply because they have lived long lives. They have knowledge and stories to assist people in their lives $[13,28,30,31]$. Laduke (2006) pronounced in her Forward in the book Grandmothers Council the World that "the words of these grandmothers are the words of real experts" [20] (p. xii). Archibald (2008) stated "Important cultural knowledge and teachings are learned carefully - over time - though interaction with Elder teachers" [16] (p. 37). It is incumbent on researchers that respectful relationships be developed with Elders. The Elders will share g' giikendaaswinmin based on relationships and trust. Many Elders share for the benefit of their children, grandchildren, and great grandchildren as part of their reciprocal relationship to life.

Numerous Elders live reciprocity by sharing g'giikendaaswinmin with those who are patient and willing to bizindam. Hall et al. (2015) stated that "[G]ifting is a gesture of a relationship between people, animals, spirits, and other entities in the universe, given in the interests of creating ties, honoring them, or asking for assistance and direction" [5] (p. 11). It is a common protocol to offer a "gift" or asemaa (tobacco) to an Elder as an exchange for g' giikendaaswinmin [32]. The exchange of asemaa dictates the responsibilities that come with kendaaswin as many Elders believe kendaaswin is a gift. Debassige (2013) stated "How something is collected, carried, and used is just as important, perhaps more so, than what is collected" [6] (p. 6). In some instances, Elders ask you to do something for them as a form of reciprocity over and above gifting. In my research, one Elder asked me to assist her in writing her third book of her teachings and life lessons. This follows Indigenous theoretical frameworks of responsibility grounded in a relational paradigm. Whyte (2018) explained that the concept of "interdependence" includes humans exercising their reciprocal relationships, nourishing, and supporting one another in diverse ways [33]. Understanding and respecting protocols, I happily obliged the Elder, assisting her with her book. Elders live interdependence by embodying respect and acknowledgement of relationality and responsibilities founded on trust.

Relationality and responsibility are founded on trust, and this is essential when working with Indigenous Elders. Trust is formed when g'giilendaaswinmin Elders share is acknowledged and used appropriately. Indigenous Elders understand that g'giikendaawinmin is place-based and redistributes g'giikendaaswinmin through family and community. I have often heard language speakers and Elders be accountable by stating, "Our Elders have said" or "I have been told" when sharing g'giikendaaswinmin. Elders constantly acknowledge and attribute who has shared g'giiikendaaswinmin. Archibald (2008) explained,

“Walter Lightening describes the authority that Elders use to teach: when Elders teach others' they very often begin by quoting the authority of Elders who have gone before. They do not state the authority comes from themselves. They will say things like 'this is what they used to say', or 'this is what they said'". (p. 37). [16]

Acknowledging g' giikendaaswinmin shared by Elders is crucial to prevent Indigenous ways of knowing and being from being marginalized, appropriated, or distorted by the western world [34,35]. Indigenous Elders will continue to work with researchers who build trust through relationality and responsibility. 


\section{Significance of Language in Research}

Anishinaabemowin is the language of the Anishinaabe Peoples, which includes the Ojibway, Ottawa, Pottawatomi, and Algonquin [31]. Many Elders are language speakers and stress the importance of learning the language. Ningewance (2004) rationalizes that when you learn Anishinaabemowin, you are also learning a new way of looking at the world [35]. Language is central to Indigenous people's lives and ties together their history, identity, spirituality, and territory, while preserving culturally unique ways of seeing and relating to the world [36-43]. Scholars wanting to learn from Anishinaabe Peoples need to understand that ways of being and ways of knowing are embedded in the language. The language is central to conveying worldviews. In many instances, concepts or words will be discussed in the language before providing a response in English.

Translation from Anishinaabemowin to English can prove difficult in understanding concepts. Corbiere (2011) explained there are several complexities in translating, because concepts are lost through translation [42]. Pitawanakwat (2019) explained that it is important to internalize the language by not force fitting it into English ways of expressing thought [41]. Archibald (2008) explained that translations lose much of the original meaning [16]. Language speakers often converse with one another until they can explain a concept in English. An example is language speakers discussing the term "reconciliation". When asked if there is a word in Anishinaabemowin for reconciliation, after several minutes of discussion, the speakers agreed on gweksidoon. They explained that gweksidoon, loosely translated, means to be putting things the right way with words from your mouth or having things the right way. They also explained the layers of the concept is dependent on who is doing the action. Couchane (2017) explained that language speakers informed him of four layers of Anishinaabemowin and at each level, you have increased complexities [43]. Kovach (2015) explained the level of meaning that is lost in translation [7]. I am not a fluent language speaker but do "understand the difficulties of using a language not one's own to construct knowledge" [44] (p. 52). The difficulties and understandings of using a different language has been acknowledged within Canada and internationally.

Researchers working in Indigenous communities must understand the importance of Indigenous languages. The languages convey worldviews and ways of being tied to place and history. It is important to provide space for the language speakers to discuss the topics of the research in their language. This ensures the research topic is understood by the language speakers and provides an opportunity for them to convey their knowledge. I have been advised many times that we must utilize our Indigenous languages, translating g'giiikendaaswinmin to English.

\section{Implications of Anishinaabek Women's Knowledge in Water Governance}

Colonization has had devastating effects on women's roles and responsibilities in relation to Anishinaabek governance. Anishinaabek women have been oppressed since the arrival of the colonizers. The Commission on the National Inquiry into the Missing and Murdered Indigenous Women and Girls (MMIWG) (2019) heard testimonies from women who argued their oppressions are primarily based on colonialism and racism. The western culture "has typically not promoted, documented or explored the culture(s) of its women" [45] (p. 30). With the imposition of the colonial laws, institutions, and governments, Anishinaabek women's roles and responsibilities have been eroded and are typically ignored. The National Inquiry into Murdered and Missing Indigenous Women: Reclaiming Power and Place, Final Report, Volume 1a dedicates a chapter to colonization as a gendered oppression. It provides a brief overview of the historical events and contexts that are at the root of the violence against Indigenous women [46]. The colonial system removed traditional structures of governance, including women's responsibilities, and attempted to dehumanize Indigenous peoples, especially women. The MMIW Final report (2019) quotes Kwagiulth (Kwakwaka'wakw) scholar Sarah Hunt, who explained "Colonialism relies on the widespread dehumanization of all Indigenous people-our children, two-spirits, men and women-so colonial violence could be understood to impact all of us at the level of our denied humanity." [46] (p. 230). The continued oppression of women is still felt today. 
However, with inquiries such as the MMIWG, recommendations have been shared on how women, with their unique relationship to the lands, can be restored in sustainable water governance.

Shkaakemaa kwe (Mother Earth) is considered feminine by Anishinaabek Peoples. Sumida Huaman and Naranjo (2019) explain how many places and landscapes are known by feminine names [37]. The settler-colonial misogyny has refused to acknowledge women's roles in N'bi governance and has created a disconnect to N'bi. Cave and McKay (2016) quoted Nehiway Spillett in saying, "The status of Indigenous women has been under attack since the colonization of our territories" [47] (p. 67). Anishinaabek women's roles and responsibilities have been disrupted in governance by colonization. Whyte (2016) explained how colonial economies disrupt relationships, such as Indigenous gender systems [33]. Women's knowledge is often dismissed and left out of sustainable N'bi governance.

Kermoal and Altamirano-Jimenez (2016) stated "[W]omen could provide a unique and valuable perspective on the emergent water crisis" [48] (p. 6). The current water governance systems have rendered Anishinaabek women's knowledge as invisible and simply not useful. Kermoal and Altamirano-Jimenez (2016) explained that ignoring Indigenous women's knowledge undermines their participation in complex socio-environmental community processes [48]. Colonization has forced a disconnect with the role of women in sustainable water governance, but this is not to say that it has paralyzed them. For example, Grandmother Josephine Mandamin began the Mother Earth Water Walks to create an awareness of the conditions of the waters. The Mother Earth Water Walks raised awareness of the responsibilities humans, including women, have to the waters [17]. Historically, many Indigenous Nations have placed a high value on women's roles and responsibilities [49]. Numerous books and articles have been compiled justifing women's responsibilities to N'bi. Anishinaabek women's knowledge needs to be an integral part of sustainable N'bi governance.

Gender is another way to understand Anishinaabe systems of responsibilities 484]. Men and women often engage in different activities and utilize different relatives (known as resources in the colonial context). Therefore, women have specific and unique kendaaswin. Anderson (2000) explained that the use of the language allows women to self-define outside of the "misogynist paradigms that exist in the colonizer's language" [45] (p. 131). Anishinaabek women have a special relationship with the waters since women have life-giving powers [10,19,24-26,50-52]. Women have a specific kendaaswin about relationships with and responsibilities to N'bi. Through the Water Walks and N'bi ceremonies, I gained a better understanding of my relationship and responsibilities to $\mathrm{N}^{\prime}$ bi as an Anishinaabe woman. Cave and McKay (2016) stated "Indigenous women share a sacred connection to the spirit of the water through their role as child-bearers and have particular responsibilities to protect and nurture water" [47] (p. 64). Anderson (2010) reiterated women's responsibilities to the waters as women are carriers of water [45]. The Water Declaration of the Anishinabek, Mushegowuk, and Onkwehonwe in Ontario (2008) states, "[T]he Anishinabek, Mushegowuk, and Onkwehonwe women are keepers of the waters, as women bring babies into the world carried on the breaking of the water" [51] (p. 1). Anishinaabe women have specific kendaaswin that can contribute to sustainable N'bi governance.

Research on sustainable N'bi governance needs to be inclusive of Indigenous women. Women possess unique kendaaswin on N'bi as the carriers of birth water. Indigenous women's kendaaswin is based on their relationships to N'bi. Sustainable N'bi governance is embedded in women's responsibility of carrying and bringing forth life through birth water. The kendaaswin women have and will offer valuable solutions for sustainable $\mathrm{N}^{\prime}$ bi governance research.

\section{Conclusions}

Researchers who want to conduct research in Indigenous communities need to educate themselves about historical unethical research. There are several books on Indigenous research methodologies or IRP that can guide researchers on conducing ethical research. Wilson et al. (2019) reiterated this-“"Indigenist research is all about relationships" [28] (p. xii). Establishing meaningful relationships 
with participants by utilizing IRP will guide research to be conducted ethically benefiting the participants and the community.

Inclusiveness of Elders is critical when conducting research in Indigenous communities. Archibald (2008) explained that "Elders are repositories of cultural and philosophical knowledge and are the transmitter of such knowledge" [16] (p. 37). In many cases, Elders are the historians of the community and bring the knowledge from the past to the present to enhance the community's identity [53]. The Elders have lived experiences, values, protocols, and community knowledge that are important in research projects. The Elders represent the knowledge of the families, communities and nations and need to be integral to research conducted in Indigenous communities. IRPs employ Elders and assure the research is unique to Indigenous Elders and their communities.

The Truth and Reconciliation's Commission of Canada (2015) lists five Calls to Action to address Indigenous languages [54]. These specific Calls to Action emphasize the importance of preserving, revitalizing, and strengthening languages [54]. The United Nations declared 2019 the International Year of Indigenous Languages [55]. In order to "action" the calls to action, along with acknowledging 2019 as the International Year of Indigenous Languages, it is incumbent upon researchers to understand the importance of Indigenous languages in research. Pitawanakwat (2018) explained that Indigenous languages are "one of the four pillars of Indigenous peoplehood" [38] (p. 461). The worldview and ways of being are embedded in the language and are not easily translated into one English word. The importance of Indigenous languages in research confirms respect for preserving and revitalizing Indigenous ways of knowing and being.

Women's knowledge is suppressed and, if not honored, the imbalance of male and female energies could cause the destruction of Mother Earth [20]. In treaty making, the waters' flow honors women and their life-giving powers. [25]. King (2007) reminds us that having these words was not mere coincidence when our Ancestors made the treaties [56]. Indigenous Peoples "tend to express and understand water as a living entity with agency or spirit to which Indigenous Peoples have reciprocal responsibilities" [24] (p. 252). Women are carriers of birth water with specific responsibilities to N'bi. Wilson (2013) stated that "Women govern the water; this role as our inherent right have never been relinquished ... [A]s women we must stand up for the water" [57] (p. 116). Women are guided by compassion and love [7] - they therefore have significant epistemic insight into how $\mathrm{N}^{\prime}$ bi can govern itself and contribute to true sustainable N'bi governance. Utilizing an IRP for research will reclaim Indigenous women's kendaaswin and forge a new future for sustainable $N^{\prime} b i$ governance.

Governance by Indigenous Peoples of the lands and waters has been recognized by international bodies as an important avenue for achieving sustainable use [58]. It would therefore be illogical to leave the Elders, the language, and women out of sustainable N'bi governance. Whyte (2018) explained how knowledge is passed from generation to generation [33] and signifies the Elders as the knowledge keepers. Meighan (2020) explained how the language informs our worldview [1]. Kermoal and Altamirano-Jimenez (2016) stated that "To ignore the specific ways in which Indigenous women know is to undermine them as active producers of knowledge that participate in complex socio-environmental processes" [48] (p. 4). Sustainable N'bi governance today and into the future relies on transformative change to meet the continuation of N'bi providing life.

Indigenous research is a celebration [8], it is ceremony [9], it is the life I immerse myself in by listening to Elders, working with the language, and standing beside women as we step into our rightful place of governance. Employing IRP for my research is testimony to recognizing and challenging the negative stereotypes of Indigenous women. My research is evidenced by Indigenous ways of knowing and being and utilizes Anishinaabek Elders', language speakers' and women's knowledge for sustainable N'bi governance.

Funding: This research received no external funding.

Conflicts of Interest: The author declares no conflict of interest. 


\section{Glossary of Anishinaabemowin to English}

Anishinaabek
Anishinaabe
Biskaabiiyang
Anishinaabemowin
Mishi zaageeng
G'giikendaaswinmin
Kendaaswin
N'bi
Ndod-ne-aah-non chi-kendaaswin
Ndakenjigewin
Minobimadziwin
Mishoomsinaanik
Nookomisinaanik
Nookomis Giizis
Bizindam
Asemaa
Gweksidoon
Shkaakemaa kwe
Mushkegowuk
Onkwehonwe

plural, used to describe Ojibway peoples singular, used to describe an Ojibway person returning to ourselves

Ojibway language

north part of Lake Huron

our knowledge

knowledge

water

I am searching for knowledge

I am actively searching for something I need to know

the good life

plural, grandfathers

plural, grandmothers

singular, grandmother moon

to listen with your entire being

tobacco

putting things right

Mother Earth

the word used by Cree people for themselves

the word the Six Nations use to describe themselves (they also use Haudeonsaune)

\section{References}

1. Meighan, P. Decolonizing English: A proposal for implementing alternative ways of knowing and being in education. Diasporaindigenousand Minority Educ. 2020. [CrossRef]

2. Absolon, K.E. Kaandossiwin: How We Come to Know; Fernwood Publishing: Black Point, NS, Canada, 2011; ISBN 978-1-55266-440-7.

3. McGregor, D. Traditional ecological knowledge and sustainable development: Towards coexistence. In The Way of Development: Indigenous Peoples, Life Projects and Globalization; Blaser, M., Fiet, H.A., McRae, G., Eds.; Zed Books: New York, NY, USA, 2004; pp. 72-91. ISBN 184-27719-2-2.

4. Mosby, I. Administering colonial science: Nutrition research and human biomedical experimentation in Aboriginal communities and residential schools, 1942-1952. Soc. Hist. 2013, 46, 145-172.

5. Hall, L.; Dell, C.A.; Fornssler, B.; Hopkins, C.; Mushquash, C.; Rowan, M. Research as cultural renewal: Applying two-eyed seeing in a research project about cultural interventions in First Nations addictions treatment. Int. Policy J. 2016, 6, 2. Available online: https:/ir.lib.uwo.ca/iipj/vol6/iss2/4/ (accessed on 11 June 2019). [CrossRef] [PubMed]

6. Debassige, B. Re-conceptualizing Anishinaabe mino-bimaadiziwin (the good life) as research methodology: A spirit-centered way in Ansihinaabe research. Can. J. Nativ. Educ. 2010, 33, 11-28.

7. Kovach, M. Indigenous Methodologies: Characteristics, Conversations, and Contexts; University of Toronto Press: Toronto, ON, Canada, 2009.

8. Lambert, L. Research for Indigenous Survival: Indigenous Research Methodologies in the Behavioral Sciences; Salish Kootenai College Press: Pablo, MT, USA, 2014; ISBN 978-1-934594-12-4.

9. Wilson, S. Research Is Ceremony: Indigenous Research Methods; Fernwood Publishing: Blackpoint, NS, Canada, 2008; p. 15. ISBN 978-1-55266-281-6.

10. Chiblow, S. Anishinabek women's Nibi Giikendaaswin (water knowledge). Water 2019, 11, 209. [CrossRef]

11. Assembly of First Nations, Environmental Stewardship Unit. Ethical Research in First Nations. 2009. Available online: https://www.afn.ca/uploads/files/rp-research_ethics_final.pdf (accessed on 15 September 2020).

12. Assembly of First Nations. First Nations Ethics Guide on Research and Aboriginal Traditional Knowledge. Available online: https://www.afn.ca/uploads/files/fn_ethics_guide_on_research_and_atk.pdf (accessed on 15 September 2020). 
13. Akwesasne Task Force on the Environment Research Advisory Committee. Protocol for Review of Environmental and Scientific Research Proposals. Available online: https://docs.google.com/viewer?a= v\&pid=sites\&srcid=ZGVmYXVsdGRvbWFpbnxhdGZlb25saW5lfGd4OjNkMDdhMmE1OGViZDk1YWQ (accessed on 15 September 2020).

14. Ontario Federation of Indigenous Friendship Centres. USAI Research Framework: Utility, Self-Voicing, Access, Inter-Relationality Second Addition. Niagara Knowledge Exchange. Available online: http://www.niagaraknowledgeexchange.com/wp-content/uploads/sites/2/2017/09/USAI-RessearchFramework_Second-Edition.pdf (accessed on 15 September 2020).

15. Guidelines for Ethical Aboriginal Research: A Resource Manual for the Development of Ethical and Culturally Appropriate Community-based Research within the First Nation Communities in the Manitoulin Area. Guidelines for Ethical Aboriginal Research Developed by Members of the Aboriginal Health Research Review Committee in collaboration with Manitoulin First Nations leadership and Community Agencies. 2003. Available online: https://www.noojmowin-teg.ca/images/GEAR_-_FINAL.pdf (accessed on 3 June 2019).

16. Archibald, J. Indigenous Storywork: Educating the Heart, Mind, Body, and Spirit; University of British Columbia; UBC Press: Vancouver, BC, Canada, 2008; ISBN 987-0-7748-1402-7.

17. Bell, N. Anishinaabe Bimmaadiziwin; living spiritually with respect, relationship, reciprocity, and responsibility. In Contemporary Studies in Environmental and Indigenous Pedagogies: A Curricula of Stories and Places; Sense Publishing: Rotterdam, The Netherlands, 2013; pp. 89-107. ISBN 978-94-6209-291-4.

18. Kimmerer, R. The fortress, the river and the garden: A new metaphor for cultivating mutualistic relationship between scientific and traditional ecological knowledge. In Contemporary Studies in Environmental and Indigenous Pedagogies: A Curricula of Stories and Places; Sense Publishers: Rotterdam, The Netherlands, 2013; ISBN 978-94-6209-291-4.

19. Anderson, K.; Clow, B.; Haworth-Brockman, M. Carriers of water: Aboriginal women's experiences, relationships and reflections. J. Clean. Prod. 2013, 60, 11-17. [CrossRef]

20. Schaefer, C. Grandmothers Counsel the World; Trumpeter Books, Shambhala Publications: Boston, MA, USA, 2006; ISBN 978-1-590-293-4.

21. Smith, L. Decolonizing Methodologies: Research and Indigenous Peoples, 2nd ed.; Otaga University Press: Dunedin, NZ, USA, 2012.

22. Sayers, J.F.; McDonald, K. A strong and meaningful role for First Nations women in governance. First Nations Women, Governance and the Indian Act: A Collection of Policy Research Reports; Status of Women in Canada: Ottawa, ON, Canada, 2001. Available online: http://www.fngovernance.org/resources_docs/First_Nation_ Women_Governance.pdf (accessed on 17 June 2019).

23. Absolon, K.; Willett, C. Putting ourselves forward: Location in aboriginal research. In Research as resistance: Critical, Indigenous and Anti-oppressive Approaches; Brown, L., Strega, S., Eds.; Canadian Scholars Press: Toronto, ON, Canada, 2005; pp. 97-126. ISBN 978-1-5513088-2-1.

24. Wilson, N.; Harris, L.; Joseph-Rear, A.; Beaumont, J.; Satterfied, T. Water is medicine: Reimagining water security through $\mathrm{Tr}^{\prime}$ 'ondek Hwech'in relationships to treated and traditional water sources in Yukon, Canada. Water 2019, 11, 624. [CrossRef]

25. Craft, A. Anishinaabe Nibi Inaakonigewin Report; University of Manitoba: Winnipeg, MB, Canada; Centre for Human Rights Research and Public Interest Law Centre: Winnipeg, MB, Canada, 2014.

26. Anderson, K. Aboriginal Women, Water and Health: Reflections from Eleven First Nations, Inuit, and Metis Grandmothers; Atlantic Centre of Excellence for Women's Health, Prairie Women's Health Centre of Excellence: Winnipeg, MB, Canada, 2010.

27. Geniusz, W.M. Our Knowledge Is Not Primitive: Decolonizing Botanical Anishinaabe Teachings; Syracuse University Press: New York, NY, USA, 2009; ISBN 978-0-8156-3204-7.

28. Wilson, S.; Breen, A.V.; Dupre, L. Research and Reconciliation: Unsettling Ways of Knowing through Indigenous Relationships; Canadian Scholars: Toronto, ON, Canada, 2019; ISBN 9781773381152.

29. McGregor, D.; Plain, S. Anishinabe research theory and practice: Place-based research. In Anishinabewin Niiwin: Four Rising Winds; Corbiere, M.A., Corbiere, A., McGregor, D., Migwans, C., Eds.; Ojibway Cultural Foundation: M'Chigeeng, ON, Canada, 2014; pp. 93-114.

30. Sinclair, N.J. K'zaugin: Storying ourselves into life. In Centering Anishinaabeg Studies; Doerfler, J., Sinclair, N.J., Stark, H.K., Eds.; Understanding the World through Stories; Michigan State University: East Lansing, MI, USA, 2013; ISBN 978-0-88755-761-3. 
31. Johnston, B. Think Indian; Languages Are beyond Price; Kegedonce Press: Cape Croker Reserve, ON, Canada, 2011.

32. LaBoucane-Benson, P.; Gibson, G.; Benson, A.; Miller, G. Are we seeking Pimatisiwin or creating Pomewin? Implications for water policy. Int. Indig. Policy J. 2012, 3, 1-22. [CrossRef]

33. Whyte, K. Settler colonialism, ecology, and environmental injustice. Environ. Soc. Adv. Res. 2018, 9, 125-144. [CrossRef]

34. Starblanket, G.; Stark, H. Towards a relational paradigm—Four points for consideration: Knowledge, gender, land, and modernity. In Resurgence and Reconciliation: Indigenous-Settler Relations and Earth Teachings; Asch, M., Borrows, J., Tully, J., Eds.; University of Toronto Press: Toronto, ON, Canada, 2018; pp. 175-207. ISBN 978-1-4875-2327-5.

35. Gonzales, P. Water-womb-land cosmologic: Protocols for traditional ecological knowledge. Ecopsychology 2020, 12, 84-90. [CrossRef]

36. Ningewance, P. Talking Gookom's Language; Learning Ojibwe; Second Printing; Mazinaate Press: Winnipeg, MB, Canada, 2017; ISBN 0-9697826-302.

37. Sumida Huaman, E.; Naranjo, T. Indigenous women and research; conversations on Indigeneity, rights, and education. Int. J. Hum. Rights Educ. 2019, 3, 1-17.

38. Pitawanakwat, B. Strategies and Methods for Anishinaabemowin Revitalization. Can. Mod. Lang. Rev./La Rev. Can. Des Lang. Vivantes 2018, 74, 460-482. [CrossRef]

39. Doerfler, J.; Sinclair, N.; Stark, H. (Eds.) Bagijige: Making an offering. In Centering Anishinaabeg Studies; Understanding the World through Stories; Michigan State University: East Lansing, MI, USA, 2013; ISBN 978-0-88755-761-3.

40. Johnston, B. The anishinaubaemowin series: The gift of the stars. In Anangoog Meegiwaewinan; Kegedonce Press: Bruce Peninsula, ON, Canada, 2010; ISBN 978-0-9784998-6-0.

41. Noodin, M. Bawaajimo: A Dilalect of Dreams in Anishinaabe Language and Literature; Michigan State University Press: East Lansing, MI, USA, 2014; ISBN 978-1-6118610-5-1.

42. Corbiere, M. Aanish go naa gaa-nendmaanh. In Anishinaabwin Niizh: Culture Movements, Critical Moments; Ojibwe Cultural Foundation: M'Chigeeng, ON, Canada, 2011; pp. 67-78.

43. Courchene, D. Language as the root of Ojibwe knowledge. Geez Mag. 2015, 39, 24-26.

44. Kovach, M. Emerging from the margins: Indigenous methodologies. In Research as Resistance: Revisiting Critical, Indigenous, and Anti-Oppressive Approaches; Strega, S., Brown, L., Eds.; Canadian Scholars Press: Toronto, ON, Canada, 2015; pp. 43-64. ISBN 978-1-55130-882-1.

45. Anderson, K. A Recognition of Being: Reconstructing Native Womenhood; Sumach Press: Toronto, ON, Canada, 2000; ISBN 1-894549-12-0.

46. National Inquiry into Murdered and Missing Indigenous Women. Reclaiming Power and Place: The Fina Report of the National Inquiry into Murdered and Missing Indigenous Women and Girls: Volume 1a. 2019. Available online: https://www.mmiwg-ffada.ca/wp-content/uploads/2019/06/Final_Report_Vol_1a-1.pdf (accessed on 13 March 2019).

47. Cave, K.; McKay, S. Water song: Indigenous women and water. Solutions 2016, 7, 64-73.

48. Kermoal, N.; Altamirano-Jimenez, I. Introduction: Indigenous women and knowledge. In Living on the Land: Indigenous Women's Understanding of Place; Kermoal, N., Altamirano-Jimenez, I., Eds.; AU Press: Edmonton, AB, Canada, 2016; ISBN 978-1-77199-04-7.

49. Green, J. Taking more account of Indigenous feminism: An introduction. In Making Space for Indigenous Feminism, 2nd ed.; Green, J., Ed.; Fernwood Publishing: Black Point, NS, Canada, 2017; ISBN 978-1-55266-883-2.

50. McGregor, D. Anishinaabe knowledge and water governance in Ontario: Honouring our Responsibilities. In Anishinaabwin Niizh: Culture Movements, Critical Moment; Corbiere, A., McGregor, D., Migwans, C., Eds.; Ojibwe Cultural Foundation: M'Chigeeng, ON, Canada, 2011; pp. 79-113.

51. Chiefs of Ontario. Water Declaration of the Anishinabek, Mushegowuk and Onkwehonwe in Ontario. 2008. Available online: http://www.onwa.ca/upload/documents/coo-water-declaration.pdf (accessed on 3 November 2019).

52. McGregor, D. Traditional knowledge: Consideratons for protecting water in Ontario. Int. Indig. Policy J. 2012, 3, 1-21. [CrossRef] 
53. Pelltier, J. And the easter bunny dies; old traditions from new stories. In Centering Anishinaabeg Studies; Understanding the World through Stories; Doerfler, J., Sinclair, N.J., Stark, H.K., Eds.; Michigan State University: East Lansing, MI, USA, 2013; ISBN 978-0-88755-761-3.

54. The Truth and Reconciliation Commission of Canada. Honouring the Truth, Reconciling for the Future: Summary of the Final Report of the Truth and Reconciliation Commission of Canada; The Truth and Reconciliation Commission of Canada: Winnipeg, MB, Canada, 2015; ISBN 978-0-660-02078-5.

55. United Nations: Department of Economic and Social Affairs. Available online: https://www.un. org/development/desa/dspd/2019/01/2019-international-year-of-indigenous-languages/ (accessed on 15 September 2020).

56. King, J.T. The value of water and the meaning of water law for the Native Americans known as the Haudenosaunee. Cornell J. Law Public Policy 2007, 16.

57. Danard, D.W. Be the water. Women Water 2013, 30, 115-120.

58. Ban, N.; Wilson, E.; Neasloss, D. Strong historical and ongoing indigenous marine governance in the northeast Pacific Ocean: A case study of the Kitasoo/Xai'xais First Nation. Ecol. Soc. 2019, 24. [CrossRef]

Publisher's Note: MDPI stays neutral with regard to jurisdictional claims in published maps and institutional affiliations.

C 2020 by the author. Licensee MDPI, Basel, Switzerland. This article is an open access article distributed under the terms and conditions of the Creative Commons Attribution (CC BY) license (http://creativecommons.org/licenses/by/4.0/). 